\title{
The Future of Community Banks: Lessons from Banks That Thrived During the Recent Financial Crisis
}

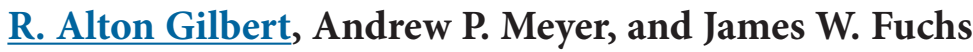

\begin{abstract}
The authors study the distinguishing features of community banks that maintained the highest supervisory ratings during the recent financial crisis (2006 to 2011). They identify balance sheet and income statement ratios that separate these thriving banks from other community banks and supplement that analysis with detailed interview evidence from a sample of thriving banks. They conclude that there is a strong future for well-run community banks and that the banks that prosper will be the ones with strong commitments to maintaining risk control standards in all economic environments. There is no one-sizefits-all strategy, however, and each bank must develop a business plan that works in its market.
\end{abstract}

(JEL G21, G28)

Federal Reserve Bank of St. Louis Review, March/April 2013, 95(2), pp. 115-43.

R. Alton Gilbert is a visiting scholar and economist emeritus, Andrew P. Meyer is a senior economist, and James W. Fuchs is an assistant vice president at the Federal Reserve Bank of St. Louis.

The authors thank William Bassett, Kevin Bertsch, Federal Reserve Board Governors Sarah Bloom Raskin and Elizabeth Duke, James Bullard, Gary Corner, Cletus Coughlin, Ron Feldman, Daigo Gubo, Jeff Gunther, Julia Maués, Gary Palmer, Robin Prager, Ken Spong, Julie Stackhouse, Todd Vermilyea, and members of the Federal Reserve's Community Bank Research Group and Community Bank Supervision Committee; the state bank commissioners in the Federal Reserve Eighth District; the Conference of State Bank Supervisors; and the St. Louis Fed's Supervisory Risk Committee and the Supervisory Policy and Risk Analysis unit for helpful comments and guidance. The authors extend special thanks to the bankers who generously participated in the confidential "thriving bank" interviews. Stephen McMorries, Matthew Morris, and Alysha Gray provided excellent research support.

( ) 2013, The Federal Reserve Bank of St. Louis. The views expressed in this article are those of the author(s) and do not necessarily reflect the views of the Federal Reserve System, the Board of Governors, or the regional Federal Reserve Banks. Articles may be reprinted, reproduced, published, distributed, displayed, and transmitted in their entirety if copyright notice, author name(s), and full citation are included. Abstracts, synopses, and other derivative works may be made only with prior written permission of the Federal Reserve Bank of St. Louis. 
Given these changes in the banking landscape, one could focus on the decline in the number of charters, the reasons for recent bank failures, and in general the many reasons certain community banks may not survive over different time horizons. This study takes a different approach: We investigate what can be learned from the operation of banks that maintained strong performance in recent years, even in the wake of the financial crisis. The thesis of our article is that the community banks that will succeed in the future will likely have characteristics similar to those of the community banks that performed well during the recent financial crisis and its aftermath. The events of recent years can be considered a real-world stress test of the community bank business model. We report on work in progress on interpreting the results of that stress test.

The next section describes our criteria for identifying the banks that performed well during the financial crisis and its aftermath, which we define as "thriving banks." First, we examine various characteristics of the thriving banks: the number that met the criteria for classification as thriving, their asset size, and their location by state. We investigate whether community banks in states with the greatest declines in economic activity in recent years could operate as thriving banks. We then compare the characteristics of the thriving banks with other community banks, which we define as "surviving banks." The surviving banks did not fail in recent years but also did not meet the criteria for thriving banks.

We use insights gained from the comparisons of the thriving and surviving banks to guide the second phase of our analysis. We selected a sample of thriving community banks and asked their leaders how their banks were able to maintain strong performance through the financial crisis and subsequent weak economic recovery. The interviews with leaders of these thriving banks indicate that they had maintained a strong commitment to conservative lending principles while competitors had relaxed their lending standards. Beyond this common commitment to conservative lending principles, the striking feature of the thriving banks we investigated is their diversity: Each appears to have found a business plan that works in its market area, but its business plan is very different from those of some of the other thriving banks we interviewed.

The diversity among the thriving banks is the basis for the third phase of our analysis, in which we examine various facets of that diversity. We then present our conclusions.

\section{THRIVING VERSUS SURVIVING COMMUNITY BANKS}

We restrict the asset size of the community banks in our study to those with total assets less than $\$ 10$ billion. This restriction is based on a definition of community banking organizations in the Dodd-Frank Wall Street Reform and Consumer Protection Act of 2010. We also exclude from our sample banks that were subsidiaries of foreign institutions at any time from 2006 through 2011. In addition, we eliminate thrifts, bankers' banks, industrial loan corporations, and cooperative banks. We eliminate banks chartered after 2001 because performance measures of de novo banks are often substantially different during their first 5 years from those of banks in operation for longer than 5 years.

Our criterion for strong performance is maintaining the highest supervisory rating, a composite CAMELS rating of 1 , during the years 2006 through the end of 2011; we refer to this condition as "thriving." (See the boxed insert for a description of the CAMELS rating system.) We choose supervisory ratings rather than specific financial ratios as indicators of a bank's health 


\section{CAMELS Ratings}

Bank safety and soundness examinations focus on six areas: capital protection (C), asset quality (A), management competence $(M)$, earnings strength $(E)$, liquidity risk exposure $(L)$, and market risk sensitivity $(S)$. Examiners assign a grade of 1 (best) through 5 (worst) to each component. In addition, they assign a composite CAMELS rating, which is also expressed on a scale of 1 through 5 . Banks with composite ratings of 1 and 2 are considered to exhibit "strong" and "satisfactory" performances, respectively. Banks that fall below a rating of 2 may prompt supervisory action, which could include a board resolution, a memorandum of understanding, a written agreement, or a cease and desist order. Hence, regulators consider a drop from a rating of 2 to a rating of 3 to be a significant change. A more detailed description can be found at http://www.fedpartnership.gov/bank-life-cycle/topic-index/bank-rating-system.cfm.

because the composite CAMELS rating captures a bank's overall financial condition plus an assessment of its management. We find that if we had looked at only performance measures such as return on assets or return on equity, we would have excluded many banks that did, in fact, thrive: Many banks with the highest supervisory rating endured the turbulence of recent years by implementing business plans that were successful but that did not yield relatively high measures of profitability.

As noted earlier, all other institutions that did not fail that fall outside these parameters are classified as "surviving banks" for the purposes of our analysis. We acknowledge, however, that many banks that did not meet our criterion for thriving banks are in sound financial condition.

We limit the banks identified as thriving banks to those with CAMELS ratings of 1 for two reasons. First, because our goal is to identify all community banks in the nation that meet our standard for thriving banks, we want to limit the number of banks in our sample. Second, some banks with a CAMELS rating of 2 (generally considered to be safe and sound) could be approaching a downgrade to a CAMELS rating of 3 . We want to exclude from the category of thriving any banks that may have been on this margin of being downgraded to a CAMELS rating of 3. In the appendix, we show that the main results of this article are not particularly sensitive to alternative definitions of "thriving."

The period for our analysis, 2006 through 2011, requires explanation. The prices of residential real estate in the United States were highest in 2006 and, as such, provide a proxy for the peak of bank performance. We then follow bank performance from this peak to a time we believe represents "end of cycle conditions"- that is, 2011.

One way to identify the end of the cycle is to examine the timing of the extraordinary actions taken by the Federal Reserve to deal with disruptions in the operations of financial markets. We focus on the timing of Federal Reserve lending operations to support the commercial paper market. The terms under which the Federal Reserve purchased commercial paper provided an incentive for firms to seek other sources of funds when the commercial paper market began to function again as a source of credit (Anderson and Gascon, 2009). Figure 1 indicates that the amount of commercial paper held by the Federal Reserve peaked in early 2009 and was close to zero by early 2010. In addition, the number of banks on the Federal Deposit Insurance Corporation's "problem bank" list peaked at 888 in 2011:Q1, up from a total of 50 banks in 2006. Observing CAMELS ratings through the end of 2011 allows us to determine whether supervisors 


\section{Gilbert, Meyer, Fuchs}

\section{Figure 1}

\section{Commercial Paper Held by the Federal Reserve System}

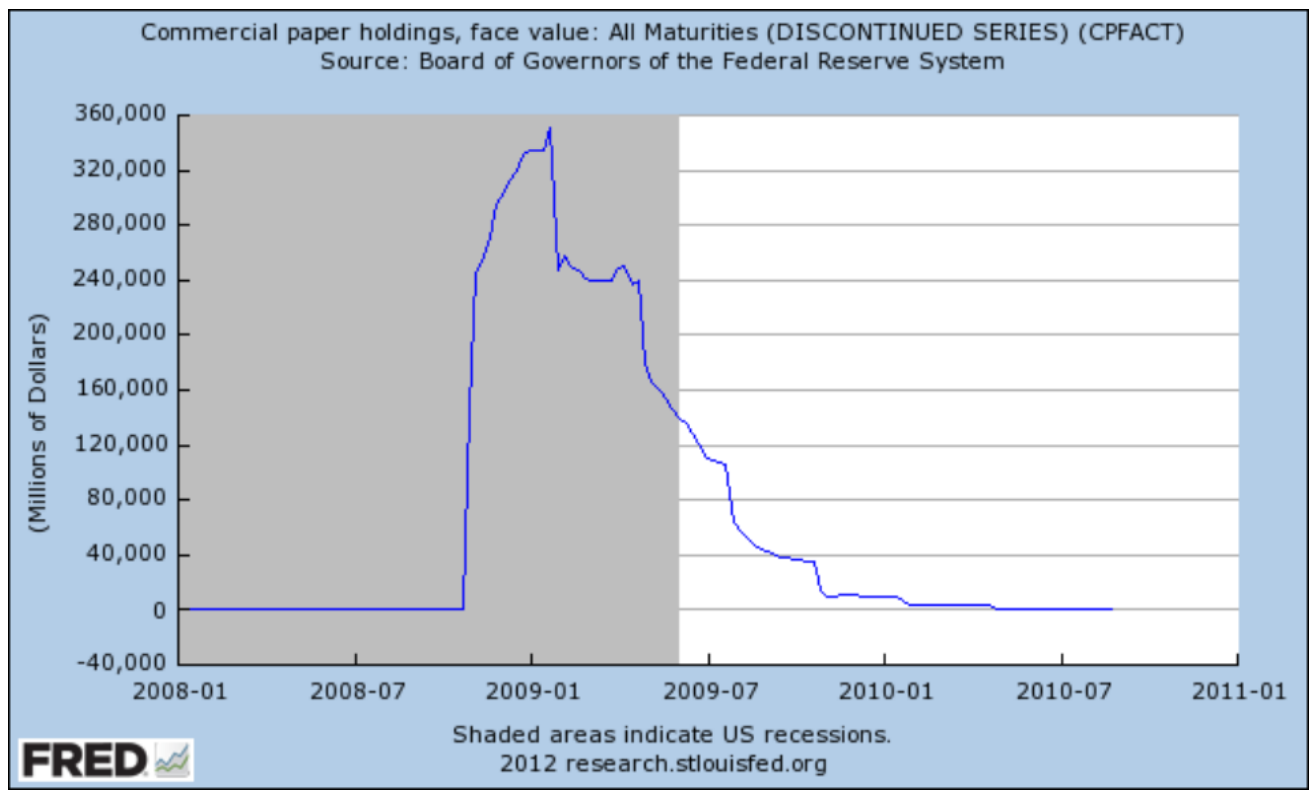

NOTE: The shaded area represents the recent recession (December 2007 to June 2009),

SOURCE: Federal Reserve Bank of St. Louis FRED (http://research.stlouisfed.org/fred2/).

confirmed the highest ratings of the thriving banks through the 12- to 18-month examination cycle that began after the end of the financial crisis. $\frac{1}{}$

To better understand the differences between thriving and surviving banks, we answer the following questions:

- How many banks met the criteria for thriving community banks, and were they concentrated in a particular asset size range?

- Were the thriving banks concentrated in states with relatively strong economic growth?

- How did the performance of thriving banks compare with the performance of surviving banks?

- Were thriving banks serving the consumers in their respective communities any better or worse than the surviving banks?

- How did the growth of thriving banks compare with that of surviving banks before and during the crisis?

- What balance sheet attributes distinguish thriving banks from surviving banks?

Table 1 indicates that 702 banks met our conditions for classification as thriving banks. The thriving banks are not concentrated in any asset size range. Many had total assets below $\$ 50$ million as of December 2011, but 36 of the thriving banks had total assets between $\$ 1$ billion and $\$ 10$ billion. These observations indicate that the secret to operating a thriving community bank does not necessarily involve keeping total assets within a certain size range. 


\section{Table 1}

\section{Asset Size of All Thriving Community Banks}

\begin{tabular}{lc} 
Asset size & No. of thriving banks \\
\hline \$1 to $\$ 10$ billion & 36 \\
\$300 million to \$1 billion & 101 \\
\$100 to \$300 million & 268 \\
\$50 to \$100 million & 158 \\
Up to \$50 million & 139 \\
Total & 702 \\
& \\
NOTE: Total assets as of December 31, 2011.
\end{tabular}

The thriving banks were located in 40 of the 50 states. Of the 702 thriving banks, 124 were located in Texas. The nine states with the largest number of thriving banks account for 73 percent of all the thriving banks. This geographic concentration appears to be related to the relative prosperity of the agricultural and energy sectors of the economy, at least through 2011.

The geographic distribution of the thriving banks, however, indicates that some community banks were able to maintain high levels of performance while operating in adverse economic environments. Table 2 ranks the states by their percentage of thriving banks. It also shows the growth of states' real gross domestic product (GDP) and the number of failed banks and banks with CAMELS ratings of 4 or 5 over the sample period. Some of the thriving banks were located in states with the sharpest rates of decline in real GDP between 2005 and 2011. For instance, real GDP in Michigan declined 10.2 percent between 2005 and 2011. The economic distress in Michigan had adverse effects on that state's banks: Nine banks failed during the 2006-11 period, and 33 banks had CAMELS ratings of 4 or 5 during these years but did not fail. And yet, four Michigan banks maintained CAMELS ratings of 1 during these years. The pattern was similar in Ohio, where real GDP declined 5.7 percent between 2005 and 2011: Two Ohio banks failed during the 2006-11 period, and nine Ohio banks had CAMELS ratings of 4 or 5 during these years but did not fail. And yet, eleven Ohio community banks maintained CAMELS ratings of 1 during these years.

Other banks, in contrast, performed poorly in more favorable economic environments. For instance, in Texas, where state real GDP increased 18.7 percent between 2005 and 2011, seven banks failed during the 2006-11 period, and 49 banks had CAMELS ratings of 4 or 5 but did not fail.

As shown in Figure 2, the regions with the fewest thriving banks are on the West Coast and in the Southeast, areas with some of the biggest declines in property values in the nation. In contrast, states with the highest concentrations of thriving banks tend to be located in the agricultural center of the country. The states with the most successful thriving banks-Louisiana (40.32 percent), Oklahoma (27.66 percent), and Texas (22.46 percent)—combine a healthy agricultural sector with a strong energy sector.

Table 3 indicates that the thriving banks indeed outperformed the surviving banks on a wide variety of performance measures. For example, throughout the sample period (2006-11), 


\section{Gilbert, Meyer, Fuchs}

\section{Table 2}

Performance of Banks in States with Different Rates of Economic Growth

\begin{tabular}{|c|c|c|c|c|c|c|}
\hline State & $\begin{array}{l}\text { State real GDP } \\
\text { growth rate (\%) }\end{array}$ & $\begin{array}{c}\text { No. of } \\
\text { thriving banks }\end{array}$ & $\begin{array}{c}\text { No. of } \\
\text { failed banks }\end{array}$ & $\begin{array}{c}\text { Nonfailing CAMELS } \\
\text { 4-5 banks }\end{array}$ & $\begin{array}{l}\text { Total No. } \\
\text { of banks }\end{array}$ & $\begin{array}{l}\text { Proportion of } \\
\text { thriving banks (\%) }\end{array}$ \\
\hline Louisiana & 4.6 & 50 & 2 & 10 & 124 & 40.32 \\
\hline Oklahoma & 10.2 & 65 & 4 & 21 & 235 & 27.66 \\
\hline Texas & 18.7 & 124 & 7 & 49 & 552 & 22.46 \\
\hline Massachusetts & 6.9 & 5 & 0 & 2 & 24 & 20.83 \\
\hline lowa & 5.7 & 66 & 1 & 18 & 333 & 19.82 \\
\hline Nebraska & 38.9 & 38 & 2 & 16 & 207 & 18.36 \\
\hline North Dakota & 29.8 & 14 & 0 & 7 & 88 & 15.91 \\
\hline South Dakota & 9.2 & 12 & 3 & 5 & 78 & 15.38 \\
\hline Kansas & 8.1 & 44 & 7 & 34 & 304 & 14.47 \\
\hline West Virginia & 7.5 & 8 & 0 & $\mathrm{~N} / \mathrm{R}$ & 58 & 13.79 \\
\hline Missouri & -0.1 & 41 & 11 & 42 & 303 & 13.53 \\
\hline New Mexico & 4.0 & 6 & 2 & 6 & 45 & 13.33 \\
\hline Kentucky & 1.8 & 19 & 0 & 20 & 178 & 10.67 \\
\hline Arkansas & 2.0 & 13 & 2 & 19 & 122 & 10.66 \\
\hline Illinois & 2.5 & 49 & 43 & 80 & 498 & 9.84 \\
\hline Minnesota & 3.0 & 36 & 17 & 74 & 366 & 9.84 \\
\hline New York & 5.4 & 11 & 4 & 11 & 118 & 9.32 \\
\hline South Carolina & 1.0 & 5 & 5 & 13 & 59 & 8.47 \\
\hline Pennsylvania & 3.8 & 11 & 2 & 13 & 130 & 8.46 \\
\hline Ohio & -5.7 & 11 & 2 & 9 & 148 & 7.43 \\
\hline Wisconsin & 1.4 & 15 & 5 & 40 & 237 & 6.33 \\
\hline Alabama & -0.4 & 8 & 4 & 23 & 134 & 5.97 \\
\hline Virginia & 5.4 & 6 & 2 & 16 & 101 & 5.94 \\
\hline Wyoming & 20.2 & 2 & 1 & 4 & 34 & 5.88 \\
\hline Colorado & 7.8 & 5 & 8 & 31 & 99 & 5.05 \\
\hline Mississippi & 3.6 & 3 & 2 & 7 & 84 & 3.57 \\
\hline Tennessee & 4.3 & 6 & 0 & 37 & 173 & 3.47 \\
\hline Michigan & -10.2 & 4 & 9 & 33 & 120 & 3.33 \\
\hline
\end{tabular}

NOTE: To avoid disclosing confidential information, statistics are not reported (N/R) for states with fewer than 10 community banks, fewer than two banks with CAMELS ratings of 4 or 5, or a thriving bank percentage less than 3.3. The state real GDP growth rates are from 2005 to 2011. The numbers of thriving banks, failed banks, and nonfailing banks with CAMELS ratings of 4 or 5 are from the main sample years of 2006 through 2011. The total number of banks and the percentage of thriving banks are from year-end 2011. 


\section{Figure 2}

\section{Percentage of Banks in Each State That Satisfy the Thriving Bank Criteria}

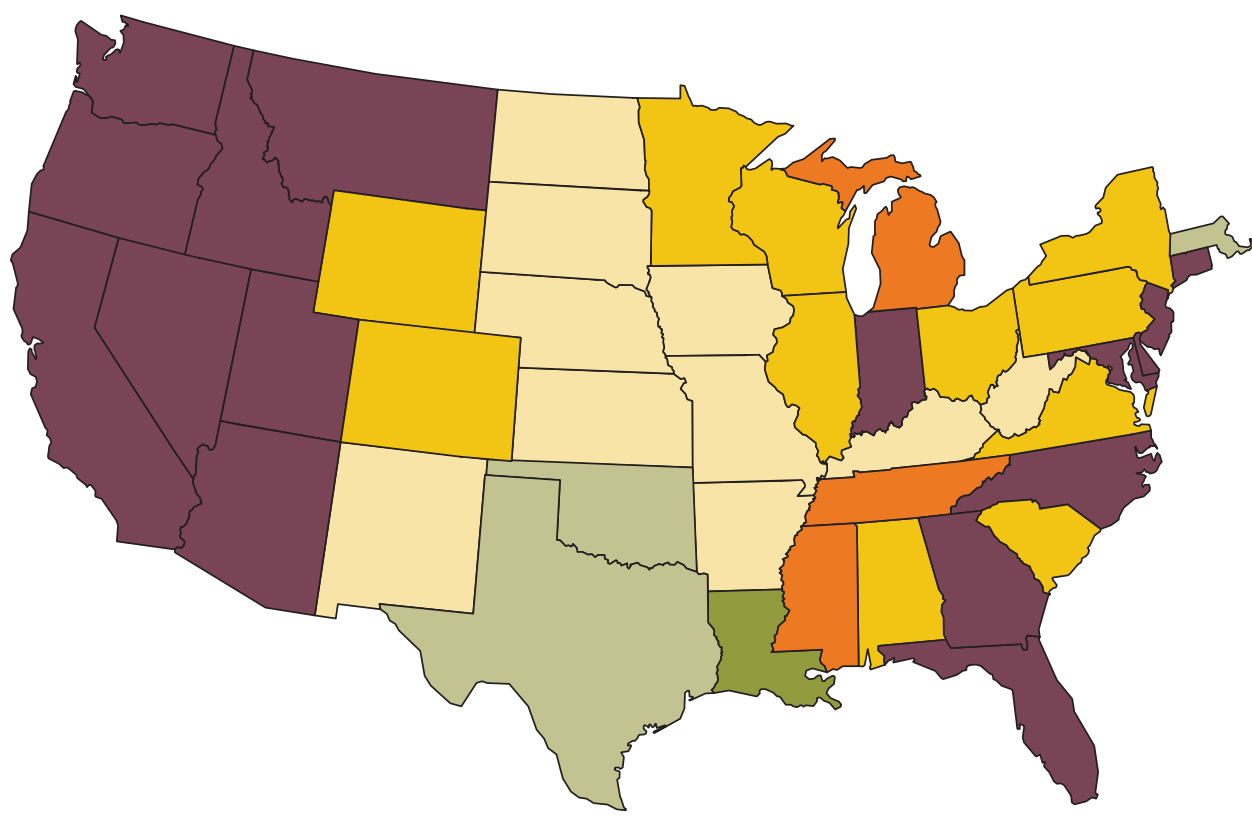

Thriving Bank Percentage

0-3.3 $\square$ 3.3-5 $\square$ 5-10 $\square$ 10-20

NOTE: See the final column of Table 2 for the exact percentages for each state with a thriving bank percentage over 3.3 percent. States with fewer than 10 community banks are excluded (Alaska, District of Columbia, Hawaii, Maine, New Hampshire, Rhode Island, and Vermont).

\section{Table 3}

\section{Performance Ratio Means for Thriving Versus Surviving Banks}

\begin{tabular}{lcc} 
Attribute & $\begin{array}{c}\text { Thriving banks } \\
(\mathbf{N}=\mathbf{7 0 2})\end{array}$ & $\begin{array}{c}\text { Surviving banks } \\
(\mathbf{N}=\mathbf{4 , 5 2 5})\end{array}$ \\
\hline ROA & $1.5 \%$ & $0.8 \%$ \\
ROE & 12.7 & 7.3 \\
Loan losses/Total loans & 0.1 & 0.5 \\
Provision expense/Average assets & 0.1 & 0.4 \\
Efficiency ratio & 61.1 & 71.8 \\
NIM & 3.7 & 3.7 \\
NNIM & 1.9 & 2.3
\end{tabular}

NOTE: Data are for U.S. community banks with less than $\$ 10$ billion in assets. All differences are statistically significant at the 1 percent level. NIM, net interest margin; NNIM, net non-interest margin; ROA, return on assets; ROE, return on equity. 


\section{Table 4}

\section{Ratings from CRA and Consumer Compliance Exams During the Crisis}

\section{Ratings}

CRA 3 or worse

Compliance 3 or worse
Thriving banks

$0.73 \%$

4.29
Surviving banks

$1.68 \%$

15.87

NOTE: Differences are statistically significant at the 1 percent level.

\section{Table 5}

\section{Growth Rates of Thriving and Surviving Banks Before and During the Crisis}

\begin{tabular}{|c|c|c|c|c|}
\hline \multirow[b]{2}{*}{ Type of bank } & \multicolumn{2}{|c|}{ Asset growth } & \multicolumn{2}{|c|}{ Loan growth } \\
\hline & 2004-07 & 2008-11 & $2004-07$ & 2008-11 \\
\hline Thriving & $23.58 \%$ & $31.16 \%$ & $31.06 \%$ & $19.68 \%$ \\
\hline Surviving & 44.28 & 26.91 & 66.04 & 18.67 \\
\hline
\end{tabular}

the mean return on assets for thriving banks was 1.5 percent, compared with only 0.8 percent for surviving banks. Thriving banks also managed a higher return on equity to their shareholders (12.7 percent versus 7.3 percent). And, as the table shows, the mean for thriving banks in the sample was better than the corresponding mean for surviving banks for every other performance measure in the table. We conclude from the data in this table that these banks are thriving in more ways than maintaining high safety-and-soundness ratings.

One question that arises is whether certain banks were able to thrive by putting more emphasis on profits than the needs of their customers. For example, a bank might limit lending in low-income neighborhoods in its market area, choose not to offer products appropriate to its low-income customers, engage in deceptive advertising or incomplete disclosures for its loan products, or discriminate against certain customers on the basis of race, gender, age, or other prohibited factors. These practices, however, would result in adverse Community Reinvestment Act (CRA) ratings and consumer compliance ratings. For each bank, we identified the worst rating for both types of consumer examinations during the sample period of 2006 through 2011. Table 4 shows the percentage of thriving and surviving banks that received less-than-satisfactory ratings. Only 0.73 percent of thriving banks had less-than-satisfactory CRA ratings compared with 1.68 percent for surviving banks. For consumer compliance examination ratings, the corresponding numbers were 4.29 percent versus 15.87 percent. Thus, we find no evidence that the thriving banks were any worse than the surviving banks in the treatment of potential customers in their communities.

Another difference between the thriving and the surviving banks can be found in the growth rates shown in Table 5. In the period leading up to the crisis (the beginning of 2004 to the end of 2007), asset growth in the surviving banks was considerably higher than in the thriving banks (44.28 percent versus 23.58 percent). Once the crisis hit, however, surviving bank growth plummeted to 26.91 percent while thriving bank growth actually increased to 31.16 percent. For total 


\section{Table 6}

\section{Selected Ratios for Thriving Versus Surviving Banks}

\begin{tabular}{lcc} 
Attribute & $\begin{array}{c}\text { Thriving banks } \\
(\mathbf{N}=\mathbf{7 0 2})\end{array}$ & $\begin{array}{c}\text { Surviving banks } \\
\text { (N = 4,525) }\end{array}$ \\
\hline Less than \$100 million in assets & $50.5 \%$ & $39.6 \%$ \\
In an MSA & 57.7 & 67.5 \\
Total loans/Total assets & 54.4 & 65.0 \\
CRE/TL & 23.3 & 34.4 \\
CLD/TL & 4.6 & 8.3 \\
Nonfarm nonresidential/TL & 17.4 & 23.8 \\
Multifamily/TL & 1.0 & 1.9 \\
Farmland-secured/TL & 11.4 & 7.8 \\
1- to 4-Family property-secured/TL & 24.4 & 23.8 \\
HELOC/TL & 1.2 & 2.5 \\
C\&I/TL & 13.7 & 14.4 \\
Consumer/TL & 10.5 & 7.6 \\
Agricultural/TL & 14.1 & 8.2 \\
All other loans/TL & 1.2 & 0.9 \\
Core deposits/Total deposits & 83.0 & 80.7
\end{tabular}

NOTE: Data are for U.S. community banks with less than $\$ 10$ billion in assets. All differences are statistically significant at the 1 percent level. C\&l, commercial and industrial; CLD, commercial and land development; HELOC, home equity line of credit; TL, total loans.

loans, the pre-crisis difference was even more stark (66.04 percent for surviving banks versus 31.06 percent for thriving banks). Once the crisis hit, loan growth for the surviving banks fell dramatically to 18.67 percent while loan growth for the thriving banks fell moderately to 19.68 percent. This pattern is consistent with our interview evidence (presented later in this article) that the thriving banks exercised a comparatively conservative growth strategy during good times and were able to capitalize on the mistakes of their competitors during bad times. The pattern is also consistent with the findings of Kiser, Prager, and Scott (2012) that small banks with ratings downgrades from 2007-10 had significantly lower rates of growth in small loans to businesses than banks that maintained healthy ratings.

Table 6 presents averages of several attributes for thriving banks and surviving banks over the 24 quarters from 2006:Q1 through 2011:Q4. Compared with the surviving banks, the thriving banks were

- smaller (a higher percentage had total assets less than $\$ 100$ million),

- more rural (a smaller percentage were headquartered in metropolitan statistical areas [MSAs]),

- less "loaned up" (i.e., had lower total loans-to-total assets ratios),

- less concentrated in commercial real estate (CRE),

- much less concentrated in construction and land development loans,

- slightly more concentrated in 1- to 4-family property mortgages held in their portfolio, 


\section{Table 7}

\section{Selected Ratios for Thriving Versus Surviving Banks}

\begin{tabular}{|c|c|c|c|c|}
\hline \multirow[b]{2}{*}{ Attribute } & \multicolumn{2}{|c|}{ U.S. urban banks } & \multicolumn{2}{|c|}{$\begin{array}{l}\text { U.S. nonagricultural } \\
\text { rural banks }\end{array}$} \\
\hline & $\begin{array}{l}\text { Thriving banks } \\
\qquad(\mathrm{N}=408)\end{array}$ & $\begin{array}{l}\text { Surviving banks } \\
\qquad(\mathrm{N}=3,047)\end{array}$ & $\begin{array}{l}\text { Thriving banks } \\
\qquad(\mathrm{N}=115)\end{array}$ & $\begin{array}{l}\text { Surviving banks } \\
\qquad(\mathrm{N}=764)\end{array}$ \\
\hline Less than $\$ 100$ million in assets & $40.8 \%$ & $31.7 \%$ & $47.2 \%$ & $43.9 \%$ \\
\hline Total loans/Total assets & 55.2 & 66.3 & 52.3 & 62.6 \\
\hline $\mathrm{CRE} / \mathrm{TL}$ & 28.8 & 39.8 & 24.3 & 31.4 \\
\hline $\mathrm{CLD} / \mathrm{TL}$ & 6.3 & 10.0 & 3.7 & 7.0 \\
\hline Nonfarm nonresidential/TL & 20.9 & 27.0 & 19.3 & 22.8 \\
\hline Multifamily/TL & 1.3 & 2.4 & 0.7 & 1.2 \\
\hline Farmland-secured/TL & 8.5 & 5.4 & 7.2 & 5.7 \\
\hline 1- to 4-Family property-secured/TL & 25.9 & 24.0 & 33.9 & 30.9 \\
\hline $\mathrm{HELOC} / \mathrm{TL}$ & 1.8 & 3.1 & 0.7 & 1.9 \\
\hline $\mathrm{C} \& \mathrm{I} / \mathrm{TL}$ & 14.4 & 14.6 & 13.2 & 14.2 \\
\hline Consumer/TL & 10.0 & 6.8 & 14.1 & 10.8 \\
\hline Agricultural/TL & 9.1 & 5.1 & 5.0 & 3.7 \\
\hline All other loans/TL & 1.2 & 0.8 & 1.0 & 1.1 \\
\hline Core deposits/Total deposits & 83.5 & 80.4 & 81.5 & 79.7 \\
\hline
\end{tabular}

NOTE: Data are for U.S. urban and nonagricultural rural banks with less than $\$ 10$ billion in assets. All differences except "All other loans/TL" are statistically significant at the 1 percent level. C\&l, commercial and industrial; CLD, commercial and land development; HELOC, home equity line of credit; TL, total loans.

- slightly less concentrated in commercial and industrial loans,

- more concentrated in consumer loans,

- more concentrated in agricultural loans, and

- more reliant on core deposits.

One reason the thriving banks were less likely than the surviving banks to be headquartered in an MSA is the good performance of agricultural loans during our sample period. There is no guarantee that the good performance of agricultural loans will continue in the future. To limit the influence of agricultural loans on the comparisons between thriving and surviving banks, Table 7 examines the differences between the attributes in Table 6 separately for urban community banks and rural community banks not classified as "agricultural" banks. The nonagricultural rural thriving banks and rural surviving banks in Table 7 had ratios of agricultural loans to total loans less than 25 percent. (Banks with ratios of agricultural loans to total loans of 25 percent or higher are identified as agricultural banks.)

As shown in Table 7, the patterns within these demographic classes are remarkably similar to the results in Table 6. That is, among urban banks as a group and among nonagricultural rural banks as a separate group, the same factors tend to lead to better long-term health.

The results in Table 7 also indicate that, compared with the thriving urban banks, the thriving rural banks were 
- smaller,

- less "loaned up,"

- less concentrated in CRE,

- more concentrated in consumer loans, but

- similarly reliant on core deposits.

The same differences hold between urban surviving banks and rural surviving banks.

Of course, a large part of good performance stems from measures of management quality and the local economic condition of the communities in which banks provide their services, both of which are difficult to quantify. To provide insight into these complex measures among banks, we studied examination reports for a sample of thriving banks and found several recurring themes. In general, thriving banks

- had a strong and localized customer service focus with high community visibility,

- operated in a thriving (i.e., growing) community,

- practiced forward-looking risk management with an eye toward long-term bank performance,

- demonstrated balance between growth objectives and risk level, and

- had patient and conservative ownership operating with the belief that returns on investment should be attractive but not necessarily spectacular.

For the factors examined, the differences between thriving and surviving banks have proven remarkably robust to the various definitions and sample splits. $\underline{3}$ The results in Tables 6 and 7 indicate that the composition of balance sheets, including relatively low ratios of loans to assets and relatively high reliance on core deposits, affects the performance of banks. Comments in examination reports indicate that thriving banks benefit from strong communities and community relationships, conservative underwriting, and good product structure.

\section{INSIGHTS FROM INTERVIEWS WITH LEADERS OF THRIVING BANKS}

In this second phase of our study, we use our findings from the statistical analysis of thriving and surviving banks and descriptions of thriving banks in examination reports to develop survey questions. Specifically, we ask senior bank management about the reasons for their bank's success. In addition, we compare our experience with the experiences of other researchers who have interviewed successful community bankers to investigate the reasons for their success. Researchers can gain insight into the determinants of bank success by interviewing leaders of community banks with consistently good performance.

\section{Study by the Federal Reserve Bank of Kansas City}

Myers and Spong (2003) conducted telephone interviews with the leaders (generally the presidents) of ten high-performing community banks in communities with relatively slow economic growth located within the Kansas City Federal Reserve District. They studied a variety of banks, from small banks with total assets as low as $\$ 15$ million to banks with established networks of branches in surrounding areas that had grown to between $\$ 100$ million and $\$ 200$ million in 


\section{Gilbert, Meyer, Fuchs}

total assets. Myers and Spong's (2003) focus is somewhat different from ours: They investigated the factors that helped community banks thrive in slow-growing communities, whereas we focus on the factors that helped community banks thrive during a severe financial crisis and economic recession.

Myers and Spong (2003) identify slower-growing market areas as counties with growth in per capita personal income in the lowest quartile of all counties in Kansas City Federal Reserve District states from 1990 to 2000. Most of these slower-growth counties were located in rural areas, especially areas far from larger cities or more scenic amenities. The authors identify the high-performing community banks in these slower-growth counties as those with average returns on equity from 1999 to 2001 in the highest quartile of all banks in Kansas City District states.

Myers and Spong (2003) conducted telephone interviews with a senior officer at each highperforming bank to derive insights into the keys to their success beyond those they could derive from financial statements and examination reports. The senior officers emphasized customer service as a key to their success. They maintained customer loyalty by keeping fees low. Officers at each of the 10 banks stressed asset quality as a key principle in their business plans and, in many cases, the most important factor in their success. Many of the leaders also cited efficient operations as a key to their success. Some bankers stressed the importance of using technology to keep operating costs low.

\section{Study by the Federal Reserve Bank of Richmond}

Brastow et al. (2012) conducted interviews with the leaders of nine state member banks in the Richmond Federal Reserve District to investigate how their banks remained in good financial condition during the recent financial crisis. The focus of their study is very similar to ours. They identified "healthy banks" as those with CAMELS ratings of 1 or 2 in 2007:Q2 that maintained ratings of 1 or 2 through 2010:Q1. They chose supervisory ratings rather than specific financial ratios as indicators of healthy banks because the composite CAMELS rating captures a bank's overall financial condition plus an assessment of its management. All institutions interviewed were community banks, but their total assets for 2010:Q3 ranged from about \$150 million to almost $\$ 4$ billion, with a mean of $\$ 1.5$ billion.

Brastow et al. (2012) emphasize the following points in their summary of the interviews.

- Commitment to conservative lending principles. Perhaps the most widely reported characteristic of the healthy bank sample was that significant time and resources were devoted to monitoring credit quality. The CEOs generally attributed their low levels of delinquent loans to detailed and careful underwriting and credit administration.

- Presence of veteran senior management, coupled with a supportive and engaged board of directors.

- Emphasis on relationship banking based on detailed knowledge of their markets and customers. The healthy banks appeared to have a good understanding of the behavior of their customers, their customers' businesses, and their local markets. In contrast, the healthy banks were reluctant to participate in markets or offer products they did not understand.

- Detailed underwriting and credit policies. Some of the healthy banks had relatively high concentrations in CRE lending but avoided the problems of other banks with high con- 
centrations of their loans in this category through detailed underwriting and credit administration policies.

\section{Interviews by the Federal Reserve Bank of St. Louis}

This section summarizes common themes revealed in our telephone interviews with leaders of a sample of thriving banks; the interview period began in April and ran through July of 2012. Table 8 lists the questions used as a guide for our conversations with leaders of 28 thriving banks. Table 9 shows the asset size ranges of the 28 banks. Table 10 lists the 19 states in which banks had their headquarters.

A common theme among several respondents was that their bank's good performance was due more to actions taken before the recent financial crisis than to any actions taken during the crisis. For example, the thriving banks did not vary from the policies and procedures established years earlier, even as other banks were seeking higher returns based on inflated asset values. Some bankers were quite candid in attributing part of their success to being in the right place at the right time. In some cases, banks benefited from booming farmland, commodity, or energy prices. Most bankers insisted, however, that in their underwriting they did not assume that high land and commodity prices would last forever.

The following summarizes the common themes among thriving community banks throughout the nation.

Conservative Lending Principles. All bankers emphasized conservative lending principles as a key to their success. A common theme in the interviews was that thriving banks were doing the things they understood. Most thriving banks interviewed limited their lending or other activities to their own communities. All bankers emphasized avoiding opportunities for which they did not have expertise. Some bankers mentioned losing business to competitors before the recent financial crisis because competitors were relaxing their lending standards. Several bankers mentioned maintaining minimum down payment percentages for loans while competitors were cutting down payments required of their borrowers. This emphasis on conservative lending principles is not surprising given that respondents were talking to staff members of a bank supervisory agency. The supervisory ratings of these banks and their general performance during recent years, however, are consistent with an emphasis on conservative lending principles.

Some bankers mentioned the work of their loan committees in maintaining high lending standards. One banker mentioned that the bank does its own underwriting of credit risk rather than relying on credit scores in making lending decisions. Another banker said that the bank identifies loans that are past due for five days or more and acts quickly to deal with problems of delinquent loans. The conservative lending principles for this bank include dealing with problems quickly. Most bankers interviewed also discussed the importance of learning from loans they ultimately had to charge off. One bank in particular required its lenders to review all charged-off loans, reassess the fundamentals of the loan at the time it was made, and communicate with management whether they would still make that loan today based on those fundamentals.

Not surprisingly, these conservative principles led to low levels of nonperforming loans and loan losses relative to peer levels. Despite this good performance, many of these thriving banks maintained a high allowance for loan and lease losses (ALLL), in some cases several times the amount of their nonperforming assets. Several bankers mentioned they maintained the bank's ALLL at the highest defensible level to provide maximum cushion for unanticipated loan losses. 


\section{Gilbert, Meyer, Fuchs}

\section{Table 8}

\section{Questions Asked of the Leaders of Thriving Banks During Telephone Interviews}

1. How were you able to keep up your good performance during the crisis?

2. What was the greatest obstacle that you had to overcome?

3. Do you plan to do anything differently as the economy improves?

4. How competitive do you perceive your local banking market to be, and what kinds of businesses do you see as your main competitors?

5. How much weight do you put on local (or regional or national) economic conditions when making a loan decision?

6. Given the demographics and other market conditions in your community, do you place a higher value on growing your bank or on maintaining stability?

7. How has your management or ownership structure helped or hurt you during the downturn?

8. What risks do you see on the horizon?

9. What opportunities do you see on the horizon?

\section{Table 9}

\section{Asset Size of Banks Interviewed}

\begin{tabular}{lc} 
Asset size & No. of thriving banks \\
\hline \$1 to $\$ 10$ billion & 2 \\
\$300 million to $\$ 1$ billion & 6 \\
$\$ 100$ to $\$ 300$ million & 10 \\
\$50 to $\$ 100$ million & 5 \\
Up to $\$ 50$ million & 5 \\
Total & 28 \\
NOTE: Total assets as of December 31, 2011.
\end{tabular}

\section{Table 10}

\section{Location of the Headquarters of the Thriving Banks Interviewed}

\begin{tabular}{lc} 
State & $\begin{array}{c}\text { No. of thriving banks } \\
\text { interviewed }\end{array}$ \\
\hline Arkansas & 1 \\
Colorado & 1 \\
Illinois & 1 \\
Indiana & 1 \\
lowa & 1 \\
Kansas & 3 \\
Kentucky & 2 \\
Louisiana & 1 \\
Michigan & 1 \\
Minnesota & 1 \\
Missouri & 2 \\
Nebraska & 1 \\
New York & 1 \\
Oklahoma & 2 \\
Oregon & 1 \\
South Dakota & 1 \\
Tennessee & 1 \\
Texas & 1 \\
Wisconsin & 1 \\
Total & 5 \\
\hline
\end{tabular}


Another "conservative" lending principle many bankers practiced either intentionally or serendipitously was avoiding the purchase of preferred shares of Fannie Mae and Freddie Mac. When these two government-sponsored enterprises were taken into government conservatorship in the fall of 2008, the prices of their preferred shares fell to fractions of the prices many banks had paid for them. Many small- and medium-sized banks bought these shares as a perceived safe haven investment in the face of severe stress in the financial markets.

The Importance of Management and Staff. In the interviews, the leaders of the thriving banks often emphasized their management teams. Some bankers focus on attracting staff from the geographic areas they serve, so their staff will know the communities they serve and will be known by the bank's customers. Some of the thriving banks have been managed by members of the same family for several generations and benefit from this depth of experience and stability in senior management. As well, this family-based structure may include a strong incentive to limit risk so the bank can be passed on to the next generation.

Another common theme among leaders of thriving banks was the importance of the "soft skills" of their staff. Several bankers went so far as to suggest that they would hire someone with great interpersonal skills over someone with a strong banking background and poor interpersonal skills. Many bankers also mentioned an attempt to gauge the character of job candidates and identified potential employees based on their experiences and interactions with them while they were working in other industry sectors in their communities.

Most leaders of thriving banks mentioned the importance of all staff members staying active in their communities. They discussed how the relationships built by their employees' community service efforts outside the bank increase bank business by creating relationships based on trust and serving community needs. One banker said his bank does not offer some services because of concern about how those services could affect their reputation in the community. Specifically, the bank does not offer (i) home equity loans because such loans may cause financial trouble for some customers who use this option and (ii) overdraft protection for transactions accounts with high fees for nonsufficient funds.

Ownership Structure and Boards of Directors. Most thriving community banks were $\mathrm{C}$ corporations, although some were $\mathrm{S}$ corporations. ${ }^{4}$ A common statement among management at thriving banks was that bank shareholders should be involved in the operation of the bank as staff or as customers and board members. Most thriving institutions were closely held, and respondents believed that the balance between management and the board was crucial. Many bankers stated their appreciation for board member involvement in helping to increase bank business and holding management accountable. They also discussed the importance of having board members who know that their task is not to "run the bank." Ownership of the shares of one bank involves an employee stock ownership plan. In addition, modest expectations by directors and shareholders for return on their shares in the bank are important for ensuring that the incentives of bank staff are skewed in the direction of limiting risk, thereby avoiding actions to reach for yield by moving into areas outside a bank's core expertise.

Distinct Business Plans of the Thriving Banks. The telephone interviews helped us understand the business plans that made it possible for individual banks to succeed in their markets. The banks interviewed are substantially different from each other, and these differences extend beyond asset size. This following text highlights some of these differences. 


\section{Gilbert, Meyer, Fuchs}

Operating Expense Ratios. Some of the thriving banks had relatively high ratios of operating expense to total assets, whereas others had relatively low operating expense ratios. The leader of one bank explained that it had relatively high ratios of operating expense to total assets because the bank emphasizes customer service. In 2011 the operating expense ratio of this bank was in the top 10 percent among its peer banks, but the ratio of pretax operating income to total assets

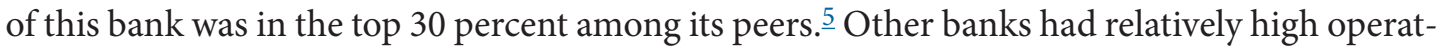
ing expense ratios because they incurred part of their operating expense by generating relatively high non-interest income.

Other banks had relatively low operating expense ratios compared with their peers. Some bankers emphasized limited investment in their facilities, including fewer offices than some competitors in their market areas. Several bankers mentioned a focus on using technology to serve customers and control costs.

Non-Interest Income. The telephone interviews provided information about the sources of non-interest income of some of the thriving banks that we could not have learned from their financial statements. The following list provides examples of sources of non-interest income that substantially boost the earnings of some of the thriving banks interviewed.

- One banker told us that his bank derives substantial non-interest income by offering accounts receivable services to businesses in its geographic area. The non-interest income of this bank in 2011 was about 1 percent of its average assets, placing it in the top 10 percent among its peer banks.

- A bank with less than $\$ 50$ million in total assets as of December 2011 derives substantial non-interest income by originating and selling loans. Non-interest income of this bank in 2011 was over 2 percent of its average assets, placing it in the top 3 percent among its peer banks.

- A bank with less than $\$ 100$ million in total assets earns substantial non-interest income by offering trust services and counting the currency for a local casino. The ratio of noninterest income to total assets for this bank in 2011 was over 1.3 percent of its average assets, placing it among the top 4 percent among its peer banks.

- One community bank generates non-interest income in the form of fees earned by providing temporary financing for residential mortgage loans originated by brokers located throughout the nation. This bank earned non-interest income in 2011 that was about 3 percent of its average assets, placing it in the top 3 percent among its peer banks.

Table 6 indicates that the thriving banks as a group have higher ratios of core deposits to total deposits than the surviving banks. Banks tend to pay lower interest rates on core deposits than other types of deposits. Several, but not all, of the thriving banks had relatively low ratios of interest expense to total assets. One banker said that the interest expense of his bank reflected the local population of senior citizens, who carefully monitor certificate of deposit rate alternatives. This bank offers relatively high interest rates on certificates of deposit to retain these customers' business. In contrast, the banks with relatively low interest expense ratios tend to have deposit liabilities concentrated in demand deposits and money market accounts.

Some of the thriving banks had relatively high concentrations of their assets in CRE, a category of lending that created serious problems at other banks. $\underline{6}$ These thriving banks maintained 
good performance through strong risk controls and thus avoided the serious problems associated with CRE lending risk that plagued other banks with weaker controls. One leader of such a bank said that they pursue "structured and disciplined credit policies" in their lending decisions. The "trick" to CRE lending at one of the thriving banks was summarized as follows: CRE lending should be limited to local (i.e., in-market), owner-occupied properties. Table 6 indicates, however, that the thriving banks as a group had lower exposure to CRE loans than the surviving banks.

Capital ratios varied substantially among the thriving banks. One thriving bank had a Tier 1 leverage ratio of about 25 percent in 2011. In contrast, another bank had a Tier 1 capital-tototal assets ratio near the bottom of the distribution among its peer banks. This second bank, however, had a supervisory rating of 1 on the capital component of its composite CAMELS rating because it had assumed little risk; about 45 percent of the bank's assets were invested in Treasury and agency securities.

\section{Comparison of Interviews of the Thriving Banks with the Kansas City and Richmond Fed Studies}

Many comments in the section on our telephone conversations with thriving banks are similar to the conclusions of the two other Fed studies. One exception involves the observation by the staff of the Kansas City Fed that the banks that performed well in slow-growth counties had relatively low operating costs. This statement is true for some, but not all, of the thriving banks we interviewed. The business plans of some of the thriving banks involve relatively high operating costs, which they incur by providing enhanced service for their customers or paying the expenses incurred in providing services that generate non-interest income.

Our telephone interviews with the leaders of thriving banks confirm a conclusion of the Richmond Fed study: Through detailed underwriting and credit administration policies, some healthy banks were able to specialize in CRE lending and yet avoided the large losses of other banks that specialized in this category of lending.

\section{Implications for Analysis of Operations of All Thriving Banks}

Interviews with the leaders of the sample of thriving banks provide insight into their business plans. The interviews indicate that community banks can thrive with a wide variety of business plans. For this reason, our analysis of the performance of all of the thriving banks in the nation focuses on their diversity, rather than on a search for a unique formula for operating a successful community bank. The good news for the community bank model is that many community banks retained the highest supervisory rating during recent years while operating in geographic areas where other community banks became problem banks or failed.

\section{EVIDENCE OF DIVERSITY AMONG ALL THRIVING BANKS}

While our telephone interviews provide valuable insight into the operations of a small number of the thriving banks, this section presents information based on the performance of all 702 thriving banks in the nation (the third phase of our study). We examined the operating characteristics of these thriving banks relative to their peers in the Uniform Bank Performance Report 


\section{Diversity in Operating Characteristics Among the Thriving Banks}

\section{Table 11A}

\section{Criteria for Assigning Banks to Peer Groups in the UBPR}

\begin{tabular}{|c|c|c|c|}
\hline Peer group no. & Total assets & $\begin{array}{c}\text { Offices in urban } \\
\text { or rural areas }\end{array}$ & No. of offices \\
\hline 1 & More than $\$ 3$ billion & Either & Any \\
\hline 2 & $\$ 1$ to $\$ 3$ billion & Either & Any \\
\hline 3 & $\$ 300$ million to $\$ 1$ billion & Either & Any \\
\hline 4 & $\$ 100$ to $\$ 300$ million & Urban & 3 or more \\
\hline 5 & $\$ 100$ to $\$ 300$ million & Rural & 3 or more \\
\hline 6 & $\$ 100$ to $\$ 300$ million & Urban & 2 or fewer \\
\hline 7 & $\$ 100$ to $\$ 300$ million & Rural & 2 or fewer \\
\hline 8 & $\$ 50$ to $\$ 100$ million & Urban & 3 or more \\
\hline 9 & $\$ 50$ to $\$ 100$ million & Rural & 3 or more \\
\hline 10 & $\$ 50$ to $\$ 100$ million & Urban & 2 or fewer \\
\hline 11 & $\$ 50$ to $\$ 100$ million & Rural & 2 or fewer \\
\hline 12 & Up to $\$ 50$ million & Urban & 2 or more \\
\hline 13 & Up to $\$ 50$ million & Rural & 2 or more \\
\hline 14 & Up to $\$ 50$ million & Urban & 1 \\
\hline 15 & Up to $\$ 50$ million & Rural & 1 \\
\hline \multicolumn{4}{|c|}{$\begin{array}{l}\text { NOTE: This table presents information about the distribution of thriving banks among their peers in the UBPR in } 2011: \mathrm{Q} 4 \text {, } \\
\text { based on various operating characteristics. The following tables for each operating characteristic present the number of } \\
\text { thriving banks and the percentage of these banks in the top } 25 \text { percent and the lowest } 25 \text { percent of the distribution } \\
\text { among peer banks. }\end{array}$} \\
\hline
\end{tabular}

(UBPR). ${ }^{7}$ Table 11A provides the criteria for assigning banks to the peer groups in the UBPR. The remaining sections of Table 11 present the percentages of thriving banks in each peer group that were in the lowest and highest quartiles among their peer banks in 2011 for various operating characteristics.

Table $11 \mathrm{~B}$ indicates that a relatively high ratio of interest income to total assets is not one of the characteristics that distinguish the thriving banks from their peers. About 36 percent of the thriving banks were in the lowest quarter of the distributions among peers in 2011, whereas only about 16 percent were in the highest quarter of the distributions. In all 15 peer groups, the percentage of thriving banks in the lowest 25 percent of each group is higher than the percentage in the top 25 percent of each group. That is, differences in asset size, locations in rural or urban areas, or number of offices do not alter the conclusion. The results in Table 11B are consistent with the finding in Table 6 that, on average, the thriving banks had lower ratios of loans to assets than the surviving banks. Because the interest rates on bank loans tend to be higher than the yields on other bank assets, lower ratios of loans to assets tend to be associated with lower ratios of interest income to total assets.

Many of the thriving banks also have relatively low ratios of interest expense to total assets: Table 11C indicates that 42 percent of the thriving banks were in the lowest quarter of the dis- 


\section{Table 11B}

Interest Income Divided by Total Assets

\begin{tabular}{lccc}
$\begin{array}{l}\text { Peer group No. } \\
\text { from UBPR }\end{array}$ & $\begin{array}{c}\text { No. of } \\
\text { thriving banks } \\
\text { in peer group }\end{array}$ & $\begin{array}{c}\text { Percentage of } \\
\text { thriving banks } \\
\text { in lowest 25 percent }\end{array}$ & $\begin{array}{c}\text { Percentage of } \\
\text { thriving banks } \\
\text { in top 25 percent }\end{array}$ \\
\hline 1 & 7 & 28.57 & 14.29 \\
2 & 28 & 42.86 & 21.43 \\
3 & 102 & 29.41 & 16.67 \\
4 & 46 & 26.09 & 21.74 \\
5 & 120 & 39.17 & 16.67 \\
6 & 27 & 51.85 & 11.11 \\
7 & 72 & 34.72 & 9.72 \\
8 & 10 & 30.00 & 0.00 \\
9 & 24 & 33.33 & 16.67 \\
10 & 31 & 41.94 & 12.90 \\
11 & 93 & 35.48 & 19.35 \\
12 & 7 & 42.86 & 28.57 \\
13 & 24 & 37.50 & 12.50 \\
14 & 30 & 40.00 & 26.67 \\
15 & 81 & 35.80 & 14.81 \\
Total & 702 & 35.90 & 16.38 \\
\hline
\end{tabular}

Table 11C

Interest Expense Divided by Total Assets

\begin{tabular}{lccc}
$\begin{array}{l}\text { Peer group No. } \\
\text { from UBPR }\end{array}$ & $\begin{array}{c}\text { No. of } \\
\text { thriving banks } \\
\text { in peer group }\end{array}$ & $\begin{array}{c}\text { Percentage of } \\
\text { thriving banks } \\
\text { in lowest 25 percent }\end{array}$ & $\begin{array}{c}\text { Percentage of } \\
\text { thriving banks } \\
\text { in top 25 percent }\end{array}$ \\
\hline 1 & 7 & 42.86 & 14.29 \\
2 & 28 & 42.86 & 7.14 \\
3 & 102 & 46.08 & 8.82 \\
4 & 46 & 39.13 & 13.04 \\
5 & 120 & 43.33 & 10.83 \\
6 & 27 & 66.67 & 3.70 \\
7 & 72 & 41.67 & 6.94 \\
8 & 10 & 40.00 & 0.00 \\
9 & 24 & 45.83 & 8.33 \\
10 & 31 & 45.16 & 19.35 \\
11 & 93 & 41.94 & 8.60 \\
12 & 7 & 28.57 & 14.29 \\
13 & 24 & 54.17 & 4.17 \\
14 & 30 & 36.67 & 13.33 \\
15 & 81 & 29.63 & 22.22 \\
Total & 702 & 42.45 & 10.97 \\
\hline & & &
\end{tabular}


Gilbert, Meyer, Fuchs

\begin{tabular}{|c|c|c|c|}
\hline \multicolumn{4}{|c|}{ Non-Interest Income Divided by Total Assets } \\
\hline $\begin{array}{l}\text { Peer group No. } \\
\text { from UBPR }\end{array}$ & $\begin{array}{l}\text { No. of } \\
\text { thriving banks } \\
\text { in peer group }\end{array}$ & $\begin{array}{c}\text { Percentage of } \\
\text { thriving banks } \\
\text { in lowest } 25 \text { percent }\end{array}$ & $\begin{array}{l}\text { Percentage of } \\
\text { thriving banks } \\
\text { in top } 25 \text { percent }\end{array}$ \\
\hline 1 & 7 & 14.29 & 57.14 \\
\hline 2 & 28 & 10.71 & 28.57 \\
\hline 3 & 102 & 6.86 & 33.33 \\
\hline 4 & 46 & 15.22 & 21.74 \\
\hline 5 & 120 & 15.00 & 30.83 \\
\hline 6 & 27 & 14.81 & 29.63 \\
\hline 7 & 72 & 22.22 & 23.61 \\
\hline 8 & 10 & 20.00 & 20.00 \\
\hline 9 & 24 & 20.83 & 29.17 \\
\hline 10 & 31 & 12.90 & 22.58 \\
\hline 11 & 93 & 27.96 & 29.03 \\
\hline 12 & 7 & 28.57 & 0.00 \\
\hline 13 & 24 & 16.67 & 33.33 \\
\hline 14 & 30 & 16.67 & 33.33 \\
\hline 15 & 81 & 35.80 & 17.28 \\
\hline Total & 702 & 18.95 & 27.49 \\
\hline
\end{tabular}

\section{Table 11E}

\section{Non-Interest Expense Divided by Total Assets}

\begin{tabular}{lccc}
$\begin{array}{l}\text { Peer group No. } \\
\text { from UBPR }\end{array}$ & $\begin{array}{c}\text { No. of } \\
\text { thriving banks } \\
\text { in peer group }\end{array}$ & $\begin{array}{c}\text { Percentage of } \\
\text { thriving banks } \\
\text { in lowest 25 percent }\end{array}$ & $\begin{array}{c}\text { Percentage of } \\
\text { thriving banks } \\
\text { in top 25 percent }\end{array}$ \\
\hline 1 & 7 & 57.14 & 14.29 \\
2 & 28 & 39.29 & 14.29 \\
3 & 102 & 38.24 & 15.69 \\
4 & 46 & 52.17 & 6.52 \\
5 & 120 & 41.67 & 10.83 \\
6 & 27 & 55.56 & 7.41 \\
7 & 72 & 36.11 & 15.28 \\
8 & 10 & 70.00 & 0.00 \\
9 & 24 & 33.33 & 8.33 \\
10 & 31 & 70.97 & 6.45 \\
11 & 93 & 41.94 & 10.75 \\
12 & 7 & 85.71 & 0.00 \\
13 & 24 & 50.00 & 8.33 \\
14 & 30 & 40.00 & 13.33 \\
15 & 81 & 55.56 & 6.17 \\
Total & 702 & 45.58 & 10.68 \\
\hline
\end{tabular}




\section{Table 11F}

\begin{tabular}{lccc}
$\begin{array}{l}\text { Income before Taxes and Extraordinary ltems } \\
\text { Peer group No. }\end{array}$ & $\begin{array}{c}\text { No. of } \\
\text { thriving banks } \\
\text { in peer group }\end{array}$ & $\begin{array}{c}\text { Percentage of } \\
\text { thriving banks } \\
\text { in lowest 25 percent }\end{array}$ & $\begin{array}{c}\text { Percentage of } \\
\text { thriving banks } \\
\text { in top 25 percent }\end{array}$ \\
\hline 1 & 7 & 0.00 & 85.71 \\
2 & 28 & 3.57 & 53.57 \\
3 & 102 & 0.00 & 62.75 \\
4 & 46 & 0.00 & 76.09 \\
5 & 120 & 0.83 & 50.83 \\
6 & 27 & 0.00 & 66.67 \\
7 & 72 & 8.33 & 43.06 \\
8 & 10 & 0.00 & 70.00 \\
9 & 24 & 4.17 & 58.33 \\
10 & 31 & 0.00 & 58.06 \\
11 & 93 & 7.53 & 40.86 \\
12 & 7 & 0.00 & 57.14 \\
13 & 24 & 0.00 & 54.17 \\
14 & 30 & 6.67 & 46.67 \\
15 & 81 & 9.88 & 43.21 \\
Total & 702 & 3.70 & 53.13 \\
\hline & & &
\end{tabular}

\section{Table 11G}

\section{Tier 1 Leverage Ratio}

\begin{tabular}{lccc}
$\begin{array}{l}\text { Peer group No. } \\
\text { from UBPR }\end{array}$ & $\begin{array}{c}\text { No. of } \\
\text { thriving banks } \\
\text { in peer group }\end{array}$ & $\begin{array}{c}\text { Percentage of } \\
\text { thriving banks } \\
\text { in lowest 25 percent }\end{array}$ & $\begin{array}{c}\text { Percentage of } \\
\text { thriving banks } \\
\text { in top 25 percent }\end{array}$ \\
\hline 1 & 7 & 57.14 & 14.29 \\
2 & 28 & 28.57 & 17.86 \\
3 & 102 & 17.65 & 38.24 \\
4 & 46 & 8.70 & 30.43 \\
5 & 120 & 17.50 & 40.83 \\
6 & 27 & 7.41 & 40.74 \\
7 & 72 & 26.39 & 34.72 \\
8 & 10 & 20.00 & 50.00 \\
9 & 24 & 16.67 & 45.83 \\
10 & 31 & 12.90 & 58.06 \\
11 & 93 & 21.51 & 38.71 \\
12 & 7 & 28.57 & 57.14 \\
13 & 24 & 20.83 & 41.67 \\
14 & 30 & 13.33 & 36.67 \\
15 & 81 & 13.58 & 44.44 \\
Total & 702 & 18.23 & 39.17 \\
\hline
\end{tabular}




\section{Gilbert, Meyer, Fuchs}

tributions. In contrast, 11 percent of the thriving banks were in the highest quarter of the distributions for this ratio.

Our telephone interviews indicated the importance of non-interest income for some thriving banks. Table 11D, however, indicates that overall, the ratios of non-interest income to total assets for thriving banks are similar to those of their peers: 27 percent in the highest quarter and 19 percent in the lowest quarter.

Table 11E illustrates the importance of relatively low operating expense for a majority of the thriving banks: Overall, the ratio of non-interest expense to total assets was in the lowest quarter of the distribution for 46 percent of thriving banks. And yet, this ratio was in the highest quarter of the distribution for 11 percent of thriving banks, illustrating the diversity among the thriving banks. In each of the 15 peer groups, however, the percentage of thriving banks with non-interest expense ratios in the lowest 25 percent among peer banks is higher than the percentage in the top 25 percent. Overall, relatively low operating expense is a general characteristic of most of the thriving banks across asset size and urban or rural location.

Thriving banks tended to have higher ratios of income before taxes and extraordinary items divided by total assets than their peers. We use pretax income as the measure of profitability because some of the thriving banks are organized as subchapter $S$ corporations (income tax paid by owners, not the banks), whereas others are not. $\frac{8}{\text { Table }} 11 \mathrm{~F}$ indicates that 53 percent of the thriving banks had ratios of pretax income to total assets in the highest quarter of the distributions; this measure of profitability was in the lowest quarter for only 4 percent of the thriving banks. This pattern of high ratios of pretax income to total assets holds for thriving banks in each of the 15 peer groups.

The thriving banks tended to have higher capital ratios than their peers, but there is substantial diversity among the thriving banks with regard to capital ratios. Table $11 \mathrm{G}$ indicates that 39 percent of thriving banks had Tier 1 leverage ratios in the highest quarter of the distributions, but 18 percent of the thriving banks had ratios in the lowest quarter of the distributions. The information from the telephone interviews indicates that the thriving banks with relatively low Tier 1 leverage ratios tended to assume relatively low credit risk.

Many of the thriving banks had relatively high concentrations in CRE. Because of concern that the loans of many banks were becoming too concentrated in CRE, the federal bank supervisory agencies issued guidelines in December 2006 for concentrations in this area of lending. 9 Under these guidelines, banks were flagged for special attention if commercial real estate loans exceeded 300 percent of risk-based capital or construction and land development loans exceeded 100 percent of risk-based capital.

Of the 702 thriving banks, 16 percent had concentrations in CRE that exceeded the federal supervisory guidelines at some point during the 2006:Q1-2011:Q4 period. Nevertheless, these banks maintained composite CAMELS ratings of 1 throughout this period. These observations indicate that the thriving banks as a group did not avoid the problems of other banks through relatively low exposures to CRE. Instead, these thriving banks were able to successfully manage the risks inherent in CRE lending.

We focus more closely on 39 of the thriving banks that exceeded one or both of these guidelines by 50 percent or more in at least one quarter during the 2006:Q1-2011:Q4 period. That is, for these banks CRE loans exceeded 450 percent of risk-based capital or construction and land development loans exceeded 150 percent of risk-based capital. 


\section{Thriving Banks with Relatively High Concentration in Commercial Real Estate Loans}

Table 12A

\section{Size Distribution of Total Assets for Thriving Banks}

Asset size

No. of thriving banks

$\$ 1$ to $\$ 10$ billion

$\$ 300$ million to $\$ 1$ billion

$\$ 100$ to $\$ 300$ million

$\$ 50$ to $\$ 100$ million

Up to $\$ 50$ million

Total

NOTE: Total assets as of December 31, 2011. This table presents information for the 39 thriving banks that exceeded one or both of the following ratios in at least one quarter from 2006:Q1 through 201:Q4: (i) commercial real estate loans that exceeded 450 percent of risk-based capital or (ii) construction and land development loans that exceeded 150 percent of risk-based capital.
Table 12B

\section{Locations of the Thriving Banks in Table 12A}

State

No. of banks

\begin{tabular}{lc}
\hline Arkansas & 2 \\
Illinois & 1 \\
lowa & 1 \\
Kansas & 2 \\
Louisiana & 7 \\
Massachusetts & 1 \\
Minnesota & 2 \\
Missouri & 4 \\
Nebraska & 3 \\
New Mexico & 1 \\
Oklahoma & 3 \\
Texas & 10 \\
Vermont & 1 \\
Virginia & 1 \\
Total & 39 \\
\hline
\end{tabular}

Table 12A presents information about these 39 thriving banks with relatively high concentrations in CRE loans. They tended to be among the larger thriving banks; 87 percent of these banks had assets above $\$ 100$ million as of December 31, 2011, compared with 58 percent for all thriving banks. These banks were headquartered in 14 states but concentrated in Texas and Louisiana (Table 12B). Supervisory ratings of these 39 banks on asset quality are relevant for determining whether examiners were critical of the quality of these CRE loans. For 17 of the 39 banks, the component of the CAMELS rating for asset quality was 1 in each examination from 2006 through 2011, and the lowest rating on asset quality was 2 for the other 22 banks. Despite these high concentrations in CRE, the bankers for these 39 thriving banks demonstrated a deep knowledge of these "concentrated" lines of business and had robust risk management controls in place in case their niche business line underperformed.

\section{CONCLUSION}

The goal of our investigation was to determine what could be learned about the future viability of U.S. community banks by examining the performance of community banks in recent years. We viewed the recent financial crisis and subsequent slow economic recovery as a realworld stress test for the community bank business model. If we were to focus on the number of banks that failed or became problem banks, the results would raise serious questions about the future viability of community banks. We focused, instead, on what we could learn from the 


\section{Gilbert, Meyer, Fuchs}

experience of community banks that performed well during recent years. The results of this investigation offer insights into the nature of the business plans that allowed many community banks to remain successful during a financial crisis and major recession.

We identified thriving community banks as those in organizations with total assets less than $\$ 10$ billion that maintained the highest supervisory rating (a composite CAMELS rating of 1) for the years 2006 through 2011. In the first phase of our analysis, we examined the size and geographic distribution of the 702 banks that met these criteria and investigated the characteristics that distinguished the thriving banks from surviving banks (the community banks that did not fail or merge out of existence during these years but did not qualify as thriving banks). In the second phase of our project, we used our findings from the comparisons of thriving and surviving banks to design a plan for interviewing leaders of a sample of the thriving banks. We conducted telephone interviews with leaders of 28 of the thriving banks to ask about the keys to their success. In the third phase, we used insights into the business plans of the thriving banks interviewed to examine various thriving bank characteristics, including interest income, interest expense, operating income, capital ratios, and CRE concentrations.

Our analysis implies there is a role for community banks in our nation's financial system in the future. The community banks that prosper in the future will have characteristics similar to those of the thriving banks interviewed: strong commitments to maintaining standards for risk control in all economic environments and business plans that work for their individual markets.

We recognize, however, that the results of our analysis are shaped by the economic environment of our sample period: 2006 through 2011. The characteristics of banks that meet the criteria for thriving banks would tend to be somewhat different if the analysis covered other years. For example, during our sample period, a concentration in agricultural lending had a statistically significant impact on whether a bank was a thriving bank. Given the increases in land prices and agricultural product prices in recent years, a positive association between agricultural lending and community bank performance is not surprising. If we were to conduct this study with data from the 1980s, however, we would tend to observe the opposite case: Concentrations in agri-

cultural lending were sources of weakness. Also, given the poor performance of banks with high concentrations of CRE during the recent financial crisis (a source of strength for community banks before 2006), it is important to view our results in the context of the period used for this study. In addition, a more forward-looking analysis of the future of community banking in the United States would take into account many additional factors, particularly the cost of regulatory compliance under the Basel III international capital accords and under the Dodd-Frank Act when fully implemented. 


\section{NOTES}

1 The date for the end of the financial crisis would be slightly different if we focused on the Term Asset-Backed Securities Loan Facility (TALF) rather than the Commercial Paper Funding Facility. Through the TALF, the Federal Reserve extended credit to investors in highly rated asset-backed securities and commercial mortgage-backed securities. The TALF opened in March 2009 and closed on June 30, 2010. If we dated the end of the financial crisis as June 30,2010 , the period from that date until the end of 2011 would cover the 18-month cycle for bank examinations.

$\underline{2}$ For the attribute "Less than $\$ 100$ million in assets" in Tables 6 and 7, we first calculate the percentage of the 24 quarters that each individual bank had total assets less than $\$ 100$ million and then calculate the mean of these percentages separately for both the thriving banks and the surviving banks. This method of creating the observations allows for patterns in which the total assets of a bank rise above or fall below the threshold of $\$ 100$ million during the 24quarter period. We use the same method to calculate the percentages of thriving and surviving banks located in an MSA. This method allows for situations in which the headquarters of a bank moved into or out of an MSA during the 24-quarter period. The other attributes in Tables 6 and 7 are ratios derived from balance sheets. We use the same method to average the financial ratios for each bank over the 24-quarter period.

$\underline{3}$ See the appendix for a detailed discussion of several alternative definitions for thriving and surviving banks.

4 Laws vary by state, but in general, an S corporation passes its taxable income or loss directly through to shareholders, whereas a $\mathrm{C}$ corporation pays taxes on the corporate income directly. There are upper limits to the asset size and number of shareholders for banks wishing to organize as an S corporation.

5 Peer banks in these comparisons are those in the peer groups of the Uniform Bank Performance Report (UBPR) described in Table $11 \mathrm{~A}$.

$\underline{6}$ One of the banks interviewed that had a relatively high concentration of loans in CRE is not included in the analysis of all thriving banks in the nation because it was chartered in 2003. We decided to exclude from the analysis all community banks chartered after 2001 because the operating characteristics of de novo banks tend to be different from those of banks that have operated for longer periods of time. If we had included the bank chartered in 2003 in the analysis of all thriving banks, it would have been included in Tables 12A and 12B as one of the thriving banks with relatively high concentrations of their assets in CRE loans.

$\underline{7}$ For more information on the UBPR, see http://www.ffiec.gov/ubpr.htm.

8 See Gilbert and Wheelock (2007) for information on how organization as subchapter S corporations affects banks' after-tax profits.

$\underline{9}$ These guidelines can be found at http://www.federalreserve.gov/boarddocs/srletters/2007/SR0701a2.pdf.

\section{REFERENCES}

Anderson, Richard G. and Gascon, Charles C. "The Commercial Paper Market, the Fed, and the 2007-2009 Financial Crisis." Federal Reserve Bank of St. Louis Review, November/December 2009, 91(6), pp. 589-612; http://research.stlouisfed.org/publications/review/09/11/Anderson.pdf.

Brastow, Ray; Carpenter, Bob; Maxey, Susan and Riddle, Mike. "Weathering the Storm: A Case Study of Healthy Fifth District State Member Banks Over the Recent Downturn." Federal Reserve Bank of Richmond S\&R Perspectives Newsletter, Summer 2012; http://www.richmondfed.org/banking/supervision_and_regulation/newsletter/2012/summer/article3.cfm.

Gilbert, R. Alton and Wheelock, David C. "Measuring Commercial Bank Profitability: Proceed with Caution." Federal Reserve Bank of St. Louis Review, November/December 2007, 89(6), pp. 515-32; http://research.stlouisfed.org/publications/review/07/11/Gilbert.pdf.

Kiser, Elizabeth K.; Prager, Robin A. and Scott, Jason R. "Supervisor Ratings and the Contraction of Bank Lending to Small Businesses." Finance and Economics Discussion Series No. 2012-59, Division of Research \& Statistics and Monetary Affairs, Board of Governors of the Federal Reserve System, August 23, 2012; http://www.federalreserve.gov/pubs/feds/2012/201259/201259pap.pdf.

Myers, Forest and Spong, Kenneth. "Community Bank Performance in Slower Growing Markets: Finding Sound Strategies for Success." Federal Reserve Bank of Kansas City Financial Industry Perspectives, October 2003, pp. 15-30; http://www.kc.frb.org/publicat/fip/prs03-2.pdf. 


\section{APPENDIX}

\section{Alternative Definitions of "Thriving" and "Surviving"}

In this appendix, we explore whether our results are robust to alternative definitions of "thriving" and "surviving." In particular, one could argue that banks with CAMELS ratings of 2 (2-rated) should not be included with the surviving banks but considered separately. One could also argue that these classifications should be based on the probability of failure or the probability of being downgraded to problem status, rather than the CAMELS rating from the previous exam. The tables in this appendix show that the basic results in the article are robust to these alternative specifications.

\section{2-Rated Banks}

We define 2-rated banks as banks that fell below a CAMELS rating of 1 (1-rated) at some point between 2006 and 2011 but never fell below a rating of 2. As shown in Tables A1 and A2, the 2-rated banks fit nicely between the 1-rated banks and the banks with ratings of 3 or worse. The differences are statistically significant in both directions. In effect, by including them in the surviving banks category, we are diluting the sample, making it look more like the thriving bank sample. If we were to combine the 2-rated banks with the thriving banks, we would dilute that sample, making it look more like the surviving bank sample. The fact that the results are consistent with our specification of thriving banks in the text provides confidence that use of another arbitrary cutoff between thriving and surviving banks would not alter our conclusions.

\section{Probability of Downgrade or Failure}

The Federal Reserve System maintains a confidential model called the Supervision and Regulation Statistical Assessment of Bank Risk (SR-SABR). One part of the model estimates the probability that a given bank will be downgraded from a CAMELS rating of 1 or 2 to a CAMELS rating of 3, 4, or 5 (i.e., from non-problem status to problem status). Another part of the model estimates the probability that a given bank will fail within the next two years. A bank with a CAMELS rating of 1 or 2 will be placed on an official "watch list" if its probability of downgrade or failure is above a preset threshold for each measure. (Banks with current CAMELS ratings of 3 or worse are automatically on the watch list.)

Thus, another natural alternative definition of thriving banks is the group of banks that remained off the watch list throughout the sample period (i.e., they maintained CAMELS ratings of 1 or 2, with downgrade or failure probabilities less than the preset thresholds). Tables A3 and A4 show the comparisons for the 1,929 banks that passed the watch list criterion. Again, the differences are all in the expected direction and all are statistically significant.

\section{Thriving Banks Versus 2-Rated Banks Not on the Watch List}

A final test involves whether 2-rated banks designated as safe by the SR-SABR model should be included among the thriving banks. (Recall that our main specification considers a bank thriving if it maintained a CAMELS rating of 1 throughout the period regardless of its downgrade or failure probabilities.) Tables A5 and A6 compare these banks with those that slipped to a CAMELS rating of 2 but nevertheless remained off the watch list because of their favorable SR-SABR ratings. The tables show that the differences are large enough to justify excluding the 2-rated banks from the thriving bank definition. As discussed previously, one could justify including them without fundamentally altering the conclusions, so the decision is ultimately a judgment call. 


\section{Table A1}

\section{Decision Variables for Three-Way Split of CAMELS Ratings}

\begin{tabular}{|c|c|c|c|}
\hline \multirow[b]{2}{*}{ Attribute } & \multicolumn{3}{|c|}{ CAMELS rating } \\
\hline & $\begin{array}{l}\text { No worse than } 1 \\
\quad(\mathrm{~N}=702)\end{array}$ & $\begin{array}{l}\text { Worse than } 1 \text { but } \\
\text { no worse than } 2 \\
(N=2,560)\end{array}$ & $\begin{array}{l}3 \text { or worse } \\
(N=1,965)\end{array}$ \\
\hline Less than $\$ 100$ million in assets & $50.5 \%$ & $43.9 \%$ & $34.1 \%$ \\
\hline In an MSA & 57.7 & 62.5 & 74.1 \\
\hline Total loans/Total assets & 54.4 & 62.6 & 68.1 \\
\hline CRE/TL & 23.3 & 28.3 & 42.3 \\
\hline $\mathrm{CLD} / \mathrm{TL}$ & 4.6 & 5.9 & 11.5 \\
\hline Nonfarm nonresidential/TL & 17.4 & 20.5 & 28.0 \\
\hline Multifamily/TL & 1.0 & 1.6 & 2.4 \\
\hline Farmland-secured/TL & 11.4 & 9.5 & 5.7 \\
\hline 1- to 4-family property-secured/TL & 24.4 & 25.4 & 21.8 \\
\hline HELOC/TL & 1.2 & 2.1 & 3.0 \\
\hline $\mathrm{C} \& \mathrm{I} / \mathrm{TL}$ & 13.7 & 14.3 & 14.6 \\
\hline Consumer/TL & 10.5 & 8.7 & 6.0 \\
\hline Agricultural/TL & 14.1 & 10.3 & 5.5 \\
\hline All other loans/TL & 1.2 & 1.1 & 0.7 \\
\hline Core deposits/Total deposits & 83.0 & 81.8 & 79.2 \\
\hline
\end{tabular}

\section{Table A2}

\section{Performance Ratios for Three-Way Split of CAMELS Ratings}

\begin{tabular}{lccc} 
& \multicolumn{3}{c}{ CAMELS rating } \\
\cline { 2 - 4 } Attribute & $\begin{array}{c}\text { No worse than } 1 \\
(\mathbf{N}=\mathbf{7 0 2})\end{array}$ & $\begin{array}{c}\text { Worse than } 1 \text { but } \\
\text { no worse than } 2 \\
(\mathbf{N}=2,560)\end{array}$ & $\begin{array}{c}\text { 3 or worse } \\
(\mathbf{N}=\mathbf{1 , 9 6 5 )}\end{array}$ \\
\hline ROA & $1.5 \%$ & $1.1 \%$ & $0.4 \%$ \\
ROE & 12.7 & 10.4 & 3.2 \\
Loan losses/TL & 0.1 & 0.3 & 0.7 \\
Provisions/TL & 0.1 & 0.2 & 0.6 \\
Efficiency ratio & 61.1 & 67.3 & 77.6 \\
NIM & 3.7 & 3.7 & 3.7 \\
NNIM & 1.9 & 2.2 & 2.5
\end{tabular}

NOTE: Data are for U.S. community banks with less than $\$ 10$ billion in assets. All differences are statistically significant at the 1 percent level. NIM, net interest margin; NNIM, net non-interest margin; ROA, return on assets; ROE, return on equity. 


\section{Table A3}

Decision Variables for SR-SABR Watch List Status

\begin{tabular}{lcc} 
& \multicolumn{2}{c}{ Watch list status } \\
\cline { 2 - 3 } Attribute & $\begin{array}{c}\text { Not on watch list } \\
\mathbf{( N = 1 , 9 2 9 )}\end{array}$ & $\begin{array}{c}\text { On watch list } \\
\text { (N = 3,298) }\end{array}$ \\
\hline Less than \$100 million in assets & $50.8 \%$ & $35.5 \%$ \\
In an MSA & 57.7 & 71.2 \\
Total loans/Total assets & 56.3 & 67.8 \\
CRE/TL & 23.3 & 38.5 \\
CLD/TL & 4.4 & 9.9 \\
Nonfarm nonresidential/TL & 17.4 & 26.1 \\
Multifamily/TL & 1.1 & 2.2 \\
Farmland-secured/TL & 10.9 & 6.8 \\
1- to 4-family property-secured/TL & 26.1 & 22.7 \\
HELOC/TL & 1.5 & 2.8 \\
C\&l/TL & 13.6 & 14.8 \\
Consumer/TL & 10.2 & 6.7 \\
Agricultural/TL & 12.9 & 6.7 \\
All other loans/TL & 1.3 & 0.8 \\
Core deposits/Total deposits & 83.4 & 79.6
\end{tabular}

NOTE: Data are for U.S. community banks with less than $\$ 10$ billion in assets. All differences are statistically significant at the 1 percent level.

\section{Table A4}

\section{Performance Ratios for SR-SABR Watch List Versus Non-Watch List Status}

\begin{tabular}{lcc} 
& \multicolumn{2}{c}{ Watch list status } \\
\cline { 2 - 3 } Attribute & $\begin{array}{c}\text { Not on watch list } \\
(\mathbf{N}=\mathbf{1 , 9 2 9 )}\end{array}$ & $\begin{array}{c}\text { On watch list } \\
(\mathbf{N}=\mathbf{3}, 298)\end{array}$ \\
\hline ROA & $1.3 \%$ & $0.6 \%$ \\
ROE & 11.4 & 6.0 \\
Loan losses/Total loans & 0.1 & 0.6 \\
Provision expense/Average assets & 0.1 & 0.5 \\
Efficiency ratio & 64.4 & 73.8 \\
NIM & 3.6 & 3.7 \\
NNIM & 2.0 & 2.4
\end{tabular}

NOTE: Data are for U.S. community banks with less than $\$ 10$ billion in assets. All differences are statistically significant at the 1 percent level. 
Table A5

Decision Variables for 1-Rated Banks Versus 2-Rated Banks Not on Watch List

\begin{tabular}{|c|c|c|c|}
\hline \multirow[b]{2}{*}{ Attribute } & \multicolumn{3}{|c|}{ CAMELS rating/watch list status } \\
\hline & $\begin{array}{c}1 \\
(\mathrm{~N}=702)\end{array}$ & $\begin{array}{l}\text { 2/Not on watch list } \\
(N=1,280)\end{array}$ & Significance \\
\hline Less than $\$ 100$ million in assets & $50.5 \%$ & $50.7 \%$ & \\
\hline In an MSA & 57.7 & 58.2 & \\
\hline Total loans/Total assets & 54.4 & 57.7 & $* * *$ \\
\hline $\mathrm{CRE} / \mathrm{TL}$ & 23.3 & 23.4 & \\
\hline CLD/TL & 4.6 & 4.4 & $* * *$ \\
\hline Nonfarm nonresidential/TL & 17.4 & 17.5 & \\
\hline Multifamily/TL & 1.0 & 1.2 & $* * *$ \\
\hline Farmland-secured/TL & 11.4 & 10.7 & $* * *$ \\
\hline 1- to 4-family property-secured/TL & 24.4 & 26.8 & $* * *$ \\
\hline $\mathrm{HELOC} / \mathrm{TL}$ & 1.2 & 1.6 & $* * *$ \\
\hline $\mathrm{C} \& \mathrm{I} / \mathrm{TL}$ & 13.7 & 13.6 & \\
\hline Consumer/TL & 10.5 & 10.0 & $* * *$ \\
\hline Agricultural/TL & 14.1 & 12.3 & $* * *$ \\
\hline All other loans/TL & 1.2 & 1.3 & $* *$ \\
\hline Core deposits/Total deposits & 83.0 & 83.5 & $* * *$ \\
\hline
\end{tabular}

\section{Table A6}

Performance Ratios for 1-Rated Banks Versus 2-Rated Banks Not on Watch List

\begin{tabular}{lcc} 
& \multicolumn{2}{c}{ CAMELS rating/watch list status } \\
\cline { 2 - 3 } Attribute & $\mathbf{1}$ & $\begin{array}{c}\text { 2/Not on watch list } \\
(\mathbf{N}=\mathbf{1 , 2 8 0})\end{array}$ \\
\hline ROA & $1.5 \%$ & $1.2 \%$ \\
ROE & 12.7 & 10.8 \\
Loan losses/Total loans & 0.1 & 0.2 \\
Provision expense/Average assets & 0.1 & 0.1 \\
Efficiency ratio & 61.1 & 66.2 \\
NIM & 3.7 & 3.6 \\
NNIM & 1.9 & 2.0 \\
NOTE: Data are for U.S. community banks with less than \$10 billion in assets. All differences are statistically significant at \\
the 1 percent level.
\end{tabular}


